\title{
India's national food security programme: a strategic insight
}

\author{
MAHESWAR SINGHA MAHAPATRA*O and BISWAJIT MAHANTY \\ Department of Industrial and Systems Engineering, Indian Institute of Technology Kharagpur, \\ Kharagpur 721302, India \\ e-mail: msmahapatra@gmail.com; bm@hijli.iitkgp.ernet.in
}

MS received 2 November 2017; accepted 29 May 2018; published online 30 October 2018

\begin{abstract}
Indian National Food Security Programme, with a goal to provide highly subsidized food grains to more than 800 million people in every nook and corner of the vast country, faces strategic challenges related to production, procurement, storage, transportation, distribution, finance, and organization. While the production issues are related to low yield, small farm size, and lack of financial support, the procurement process is skewed and lacks integration with the markets. The storage facilities are inadequate and are non-optimally located. Transportation facilities lack coordination leading to multiple loading and unloading of the food grains. Leakage and improper distribution of food grains are also big challenges. Very high subsidy, inefficient processes, and a large work force have brought to the fore the question of financial viability of the programme. There are also organizational issues related to payment disparity and resistance to labor reforms. The paper has also given a framework for efficient implementation of the programme using cloud system with effective procurement and stock management policy measures.
\end{abstract}

Keywords. Indian food security programme; food supply chain; strategic challenges; cloud system.

\section{Introduction}

India runs world's largest food programme, which provides highly subsidized food grains to more than 800 million people. Success of this program is critical to India in addressing food security.

Experts have contradictory opinions in evaluating the impact of National Food Security Act 2013 considering its enormous cost of implementation and a substantial amount of leakage (about 40-50 per cent) in the supply chain [1].

Indian food programme considers three broad objectives. These are: (i) providing highly subsidized food grains to targeted people, (ii) ensuring price support to farmers, and (iii) price stabilization over the year. These objectives are integrated in planning and execution of the program thus making it unique among other food programmes in the world.

Food Security, as defined by World Food Summit in 1996, "exists when all people, at all times, have physical, social and economic access to sufficient, safe and nutritious food which meets their dietary needs and food preferences for an active and healthy life". In view of this, the Indian food programme can be evaluated as a mixed bag of success and failure considering its length of operation. From a success point of view, India has become self-reliant in food grains production. Although total undernourished people in

*For correspondence
India remained at about 200 million for the past two decades, the ratio of undernourished people to total population has declined from 23.7 per cent in 1990-92 to 15.2 per cent in 2014-16 [2]. In the case of adequate price support to farmers, success remained confined to a few Indian states such as Punjab, Haryana, Andhra Pradesh and Chhattisgarh for rice and Madhya Pradesh for wheat. Farmers in the other Indian states remained vulnerable to open market price and high price variation due to a lack of market integration [3-5]. On the price stabilization front, India has maintained a steady food grain price in the domestic market in comparison to the international market. However, in doing so, a huge subsidy has to be paid. The subsidy to the food programme has increased from INR 28.5 billion in 1991-92 to INR 1349.19 billion in 2015-16, a 47-time increase in 24 years. The share of food subsidy to the total subsidy has also increased from 23.3 per cent to 55.78 per cent over the same period.

On this backdrop, this paper presents the strategic challenges prevalent in the Indian National Food Security Programme highlighting all the areas of concern. Rest of the paper is organized as follows. Section 2 describes a brief history of policy initiatives already implemented in the food programme. Section 3 discusses the strategic challenges present in the food programme in production, procurement, storage, transportation, distribution, financial and organizational dimensions. Section 4 presents a framework for efficient implementation of the program 
using cloud system which is followed by an impact analysis on global market in section 5. Finally, section 6 concludes the paper with the analyzed outcomes.

\section{Indian food program}

India's food programme was established under British rule in the form of Public Food Distribution System (PFDS) in the backdrop of World War II and Bengal Famine in 1943 [6]. Urban and food deficit regions were the primary targets in the initial stage of the program. From mid-1960, Indian government took an integrated food and agriculture policy for attaining self-sufficiency in food grain production, maintaining price stabilization and safeguarding poor consumer's interest [7]. With time, both food grain production and coverage under the public distribution system (PDS) increased in leaps and bounds, and by 1990, it almost covered the entire population.

Indian government set-up Food Corporation of India (FCI) and Agriculture Price Commission (APC) in 1965. The FCI takes part in procurement, storage and transportation of food grains to deficit states whereas the PDS in the state ensures distribution of food grains to targeted people. To ensure remunerative product price for the farmers, APC (renamed as Commission for Agriculture Costs and Prices in 1985) recommends Minimum Support Price (MSP) for selected agriculture commodities. In 1997-98, the government introduced Decentralized Procurement (DCP) scheme for efficient procurement, storage and distribution of food grains. As of now, 15 States/Union Territories have implemented the scheme. Decentralized Procurement scheme has become successful in many states such as Chhattisgarh, Madhya Pradesh and Odisha. Figure 1 describes basic operations of the food programme and identifies concerned agencies involved in these operations.

The price support system for the farmers is as follows. The government announces procurement prices for food grains before harvesting season and also proposes to buy a specified amount from the farmers based on the requirement. They also announce Minimum Support Price (MSP) before sowing, which works as a floor price for any amount of procurement by the government. However, of late, the government has stopped announcing procurement prices and MSP is used for public procurement.

Various studies showed that price stabilization is at the heart of the food programme in India [8, 9]. The food programme achieves this goal by building up a large stock of food grains. This 'Buffer Stocking' policy is used not only to combat price volatility but also to ameliorate agricultural production of the food grains. Apart from these, Indian government carries out market regulation through the Essential Commodity Act, restriction of inter-state trade, and zoning policy to ensure easy procurement of food grains from surplus regions [7]. Later in 2002-03, the

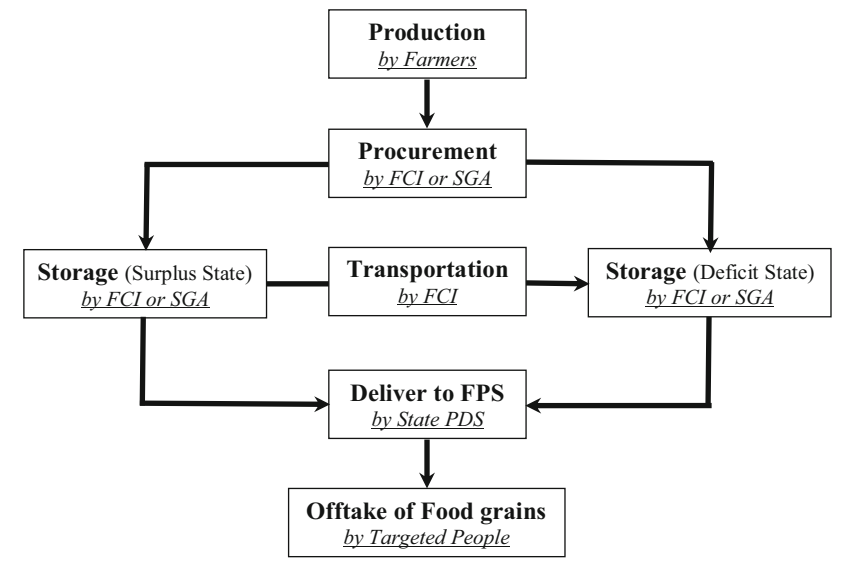

Figure 1. Basic Operations and Agencies involved in the Food Programme. (FCI: Food Corporation of India, SGA: State Government Agency)

government removed inter-state trade barrier on specified food items.

Analyzing government policies on food programme prevailing in various countries, Cummings Jr. et al [8] elaborated the role of government in successful implementation of the food programme in Asia while achieving grain price stabilization. Sharma and Gulati [10] described the experience in improving food security in countries such as China, India, Brazil, Malaysia, Mexico and Nigeria. They found that China and Brazil are better in achieving availability, access and utilization of food. A study on the food programme in India and Bangladesh by Banerjee et al [6] found that while Bangladesh is able to reduce the role of the government through various measures, India is unable to reduce government involvement in the food programme. Yu et al [11] analyzed the difference of policies in ensuring food security in India and China. While China provides direct transfer of agriculture subsidy, food access and other safety nets, India uses price based subsidy to farmers and direct delivery of food.

Table 1 gives the broad strategic challenges in various areas of the Indian food programme. The strategic challenges are highly interconnected with one another.

\section{The strategic challenges}

This section presents the strategic challenges in the Indian food programme in production, procurement, storage, transportation, distribution, financial and organizational dimensions. We also discuss recent policy measures and potential capabilities in each dimension.

\subsection{Production}

3.1a Low yield: India has achieved food grain sufficiency decades back, although average yield is still quite low in 
Table 1. Broad strategic issues in Indian Food Programme.

\begin{tabular}{|c|c|}
\hline Areas & Strategic challenges \\
\hline Production & $\begin{array}{c}\text { Low yield } \\
\text { Small Farm Size } \\
\text { Limited financial support }\end{array}$ \\
\hline Procurement & $\begin{array}{l}\text { Skewed procurement } \\
\text { Open procurement policy } \\
\text { Lack of market integration }\end{array}$ \\
\hline Storage & $\begin{array}{l}\text { Lack of silos and use of CAP } \\
\text { Skewed storage facility } \\
\text { Longer stock holding }\end{array}$ \\
\hline Transportation & $\begin{array}{l}\text { Excessive transportation } \\
\text { Multiple loading and unloading } \\
\text { Lack of coordination }\end{array}$ \\
\hline Distribution & $\begin{array}{l}\text { Eligibility checking } \\
\text { Leakage of food grain } \\
\text { Financial viability }\end{array}$ \\
\hline Financial & $\begin{array}{l}\text { Increasing demand } \\
\text { High Economic Cost and Low Issue Price } \\
\text { Increasing support price } \\
\text { Large work force }\end{array}$ \\
\hline Organizational & $\begin{array}{l}\text { Payment disparity } \\
\text { Resistance to labor reforms }\end{array}$ \\
\hline
\end{tabular}

comparison with US, Europe or China [12]. Northern Indian states are found to be more productive compared to other Indian states. Punjab in the northern region is the most productive state with rice productivity at 3.79 ton/ hectare and wheat productivity at 4.38 ton/hectare in the last decade. Figure 2 shows a pictorial view of production and procurement details of rice and wheat across the Indian states using color gradients. On the national perspective, net cultivated area (approx. 141 million hectares) has not increased much over the past decades, even as gross cultivated area has increased to almost 200 million hectares by increasing cropping intensity [13]. Almost half of the net cultivated area is out of irrigation facility.

3.1b Small farm size: The proportion of marginal landholders (less than one hectare) in India has increased from 62.9 per cent in 2000-01 to 67.1 per cent in 2010-11. Apart from this, 18 per cent are small landholders (between one and two hectares), 10 per cent are semi-medium landholders (between two and four hectares) and the rest are medium to large landholders. Because of the prevalence of small and marginal landholders, the cost of cultivation per hectare in India remains high. The use of modern equipment is also minimal among most of the farmers. It is also a fact that most of the modern equipment cannot be used efficiently in smaller farms.

3.1c Lack of financial support: Most of the small and marginal landholders are beyond the reach of financial institutions and are forced to borrow from local lenders with high interest, which leads to higher farming cost. Moreover, lack of market integration [3-5] leads to higher price volatility, which deprives the farmers in getting due price for their produce.

3.1d Potential for future: India has huge potential to increase food grain production with lesser effort as most of the large states have low productivity. Proper irrigation, better quality seed, modern techniques and fertilizer can augment productivity in these states. India has sustained two consecutive droughts without much impact in recent time [14], which clearly shows the resilience of Indian agriculture system [15]. New insurance policy (http://agriinsurance.gov.in/pmfby.aspx) is implemented with facilities such as enhanced risk coverage from pre-sowing to post-harvest losses, lower premium ( 2 per cent and 1.5 per cent of sum insured for kharif and rabi crops respectively), and use of remote sensing technology for early claim settlement to protect farmers' interest against uncertainty due to natural calamity, crop damage, or low yield. It will also encourage the adoption of innovative and latest agriculture practices and help in a smooth flow of credit. New irrigation policy with the target of 'per drop more crop' may improve on-farm water use efficiency and promote sustainable water conservation practices such as arresting depletion of groundwater and preserving soil health [16]. Right crop selection [17] may also play an important role in this regard.

On global perspective also, India can play an important role according to Tilman et al [18]. He advocates the adoption of high yielding crops for countries like India rather than going for agriculture intensification. The policy may save almost 0.8 billion hectare of land clearing, twothird of greenhouse gas emission and considerable reduction in Nitrogen use.

\subsection{Procurement}

3.2a Skewed procurement: Public procurement of food grains is limited to a few Indian states only. The skewedness is more pronounced in wheat in comparison to rice in terms of both production and procurement (see figure 2). Almost 70 per cent of rice is procured from the Indian states of Punjab, Andhra Pradesh, Chhattisgarh and Odisha, while almost 90 per cent of total wheat is procured from Punjab, Haryana and Madhya Pradesh. Because of this, farmers in others states remain out of the price support programme. Similar statistics is also found in High-level Committee report [19]. They report that out of 90.2 million household connected to agriculture during July to December 2012; only 18.67 million are reported to be in the price support programme.

3.2b Open procurement policy: Under open procurement policy, the government buys as much as the farmers would sell with a pre-specified quality. The policy led to a skewed procurement pattern with higher procurement of food grains in only a few Indian states. Additionally, the high 

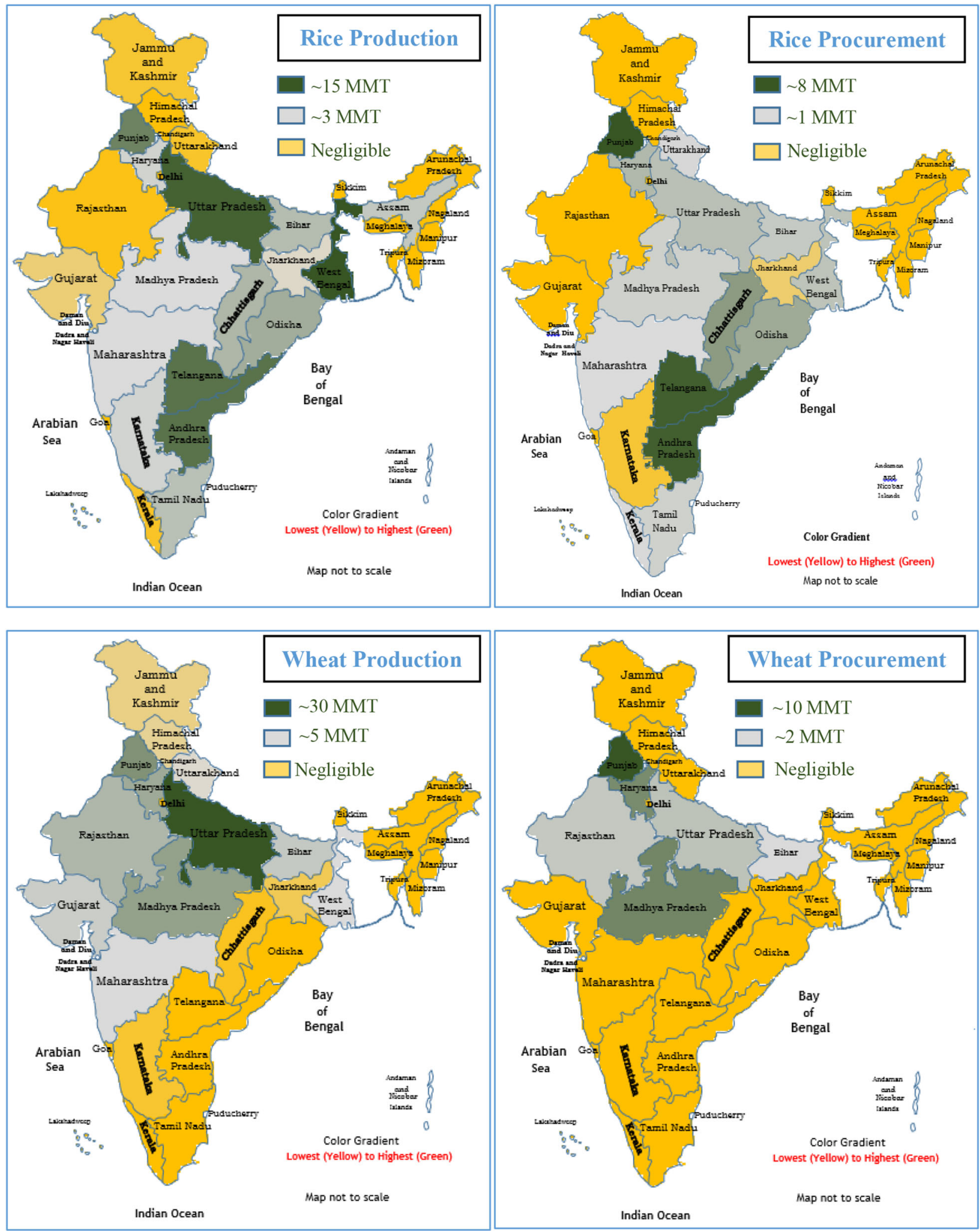

Figure 2. Production and procurement scenario in India.

procuring states increase statutory levies (i.e., state tax) over the years that lead to the increase in procurement expenditure (termed as procurement incidentals). The amount paid to the states as statutory levy was as high as 10 per cent of the total food subsidy in 2011-12 [20]. As an alternative, a policy of 'competitive procurement' on the 


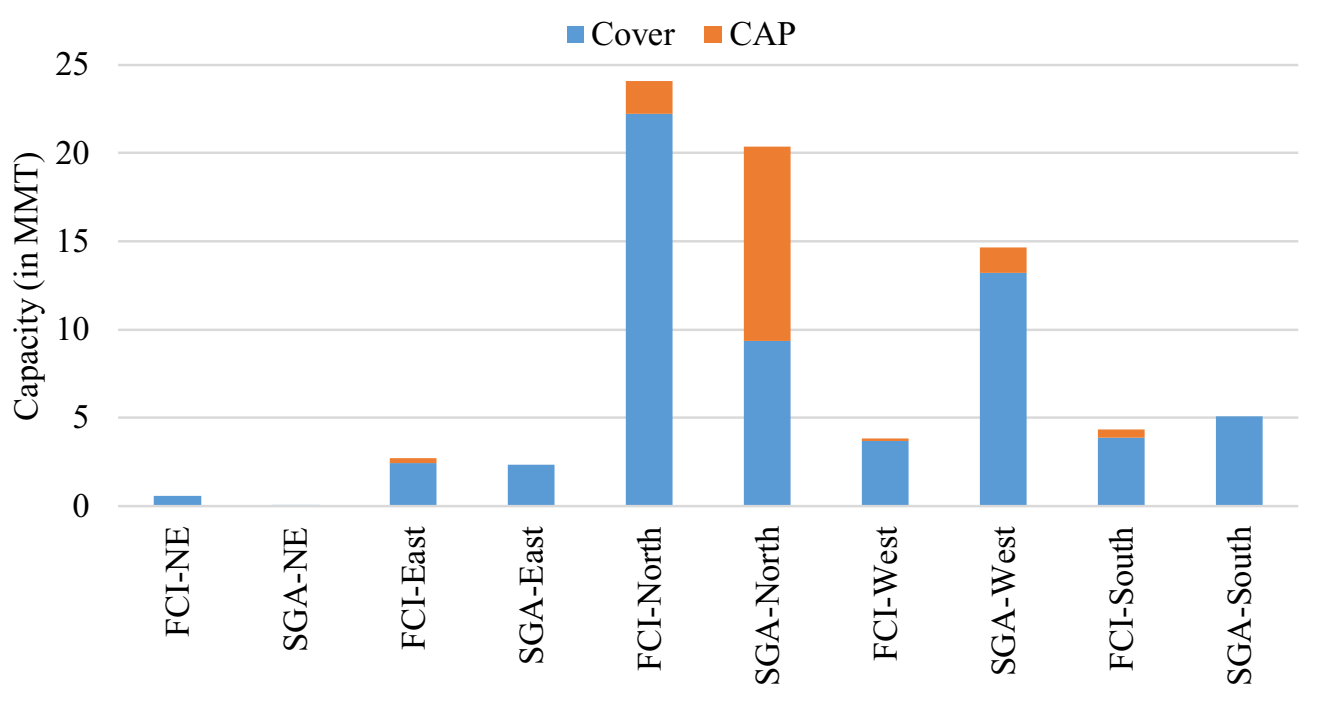

Figure 3. Storage capacity based on zones under FCI and SGA. Data Source: Annual Report 2016-17, DFPD.

basis of least effective unit cost may yield better results in terms of maintaining reasonable market price across country, reduce skewedness in procurement across state, and attract private players in the procurement of food grains.

Apart from the 'open procurement policy', 'bonus payment' in addition to MSP leads to sharp disparity in private and public procurement in a few states. Realizing the impact of this policy, the government has scrapped the 'bonus payment' in 2015 to bring back private players in procurement. Under this plan, government (Central) will not take ownership of additional procurement beyond the requirement of the concerned state in case of violation [21].

3.2c Lack of market integration: Various studies [3-5] have expressed that lack of market integration is a shortcoming in the Indian food programme. There are about 7000 wholesale markets in India to provide fair price to farmer but are monopolized by middlemen [22]. These markets are controlled and managed by individual administrative committees, which lead to fragmented markets and minimal market integration. As a result, farmers do not get due price for their products. Market integration helps in maintaining stable price of the food grains for both the consumers and the farmers. Use of digital platform may improve the scenario by removing a large number of middlemen and benefitting the farmers.

3.2d Potential for future: A few Indian states improved public procurement of food grains in the last decade using decentralized procurement (DCP) policy. These states include Chhattisgarh and Odisha in paddy procurement and Madhya Pradesh in wheat. High Level Committee report in 2015 also suggested the use of DCP across the states. With production of food grain on the rise, there is hope for the low procuring states to increase procurement with time.
Taking cue from Viswanadham et al [23], the mandis (local markets) need to transform to electronic exchange places where both farmers and buyers gain armed with better information. The e-NAM (http://www.enam.gov.in) would pave the way in the development of a unified integrated market that would eventually reduce the requirement of public procurement. Implementation of GST will remove high statutory taxes that are usually prevalent in the high procuring states. As a result, the procurement incidentals cost will come down which presently is about 17 per cent of the total economic cost.

\subsection{Storage}

India faced major storage issues in the last decade, when the Central Pool (i.e., total stock held by FCI and SGA for public distribution) stock reached a value of 82.4 MMT in June 2012. Comptroller Auditor General (CAG) of India [24] reported that there was a storage gap of 33.2 MMT in March 2012.

3.3a Lack of silos and use of CAP: Storage facilities used in India are mainly covered godowns (including silos) and CAP (Cover and Plinth). Cover and Plinth (CAP) is a storage facility for food grains in the open with low establishment cost for a short period. In CAP, which is about 20 per cent of the total storage capacity, bagged food grains are stacked on a plinth and are covered with thick polyethylene (250 microns). However, use of CAP beyond the stipulated time led to huge food grain loss in the past.

3.3b Skewed storage facility: India has 62.8 MMT of covered capacity and 15 MMT of CAP at present. Figure 3 shows zone-wise distribution of storage capacity along with their ownership. Half of the total covered capacity lies in 


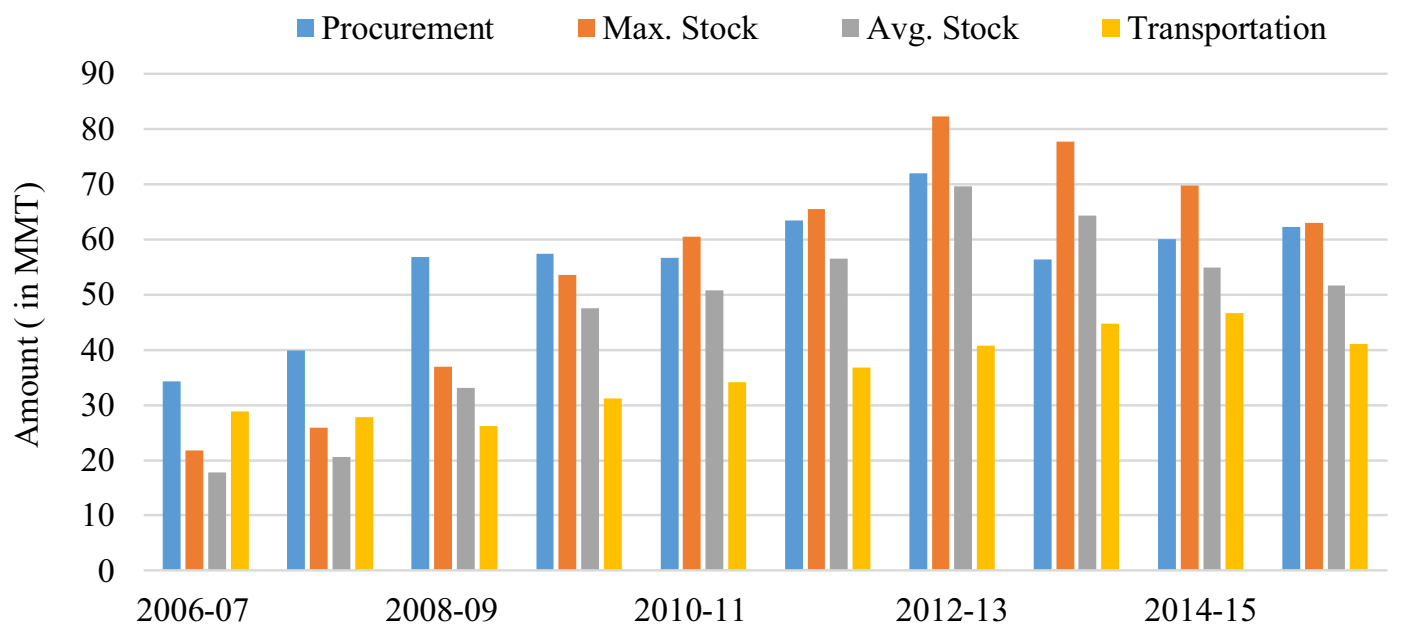

Figure 4. Procurement, stock and transportation from 2006-07 to 2015-16. Data Source: Food Corporation of India.

the northern zone. Eastern and north-eastern zones together hold only 7.5 per cent of the total storage capacity. This skewed distribution of storage facilities can be attributed to skewed procurement.

3.3c Longer stock holding: Holding food grain stock for longer period not only degrades the quality but also leads to faster quantity loss. As per 2015 e-book of Department of Food and Public Distribution, the food grain is sometime held for a two-year period. To provide quality food grain to the targeted people, the stock holding period should reduce substantially. FCI should use First-In-First-Out (FIFO) policy effectively and release additional stock on a timely basis.

Sometimes, a higher stock of food grains is resulted because of government policies. For example, in 2007-08, Indian government banned export of food grains with rise of price in the international market. That led to fast buildup of food grain stock in the Central Pool to a value of 82.4 MMT (see figure 4). It may be noted that, during the same period (i.e., 2008-2013), India faced around 10 per cent of average inflation. High cost was incurred for carrying such a huge inventory. The government also could not reduce food grain procurement due to political compulsions even though enough food grains were stocked in the Central Pool.

3.3d Potential for future: Realizing the need for better storage facility, FCI has involved private parties with assured rent under Private Entrepreneurs Guarantee (PEG) scheme to phase out CAP. FCI has also planned to build silos of total capacity 10 MMT under various PPP schemes in key procuring and demand zones that can potentially change the storage scenario in India. It would not only reduce manual loading and unloading but would also reduce significant amount of food grain loss in the process.

\subsection{Transportation}

Indian Railway is the backbone of food grain movement in India, and over 90 per cent of food grain is transported by this mode. FCI executes the whole movement plan.

3.4a Excessive transportation: About 60 per cent of the total food grain procured was required to be transported from one region to another in the last decade. Movement of food grains has increased from 26.14 MMT in 2008-09 to 44.78 MMT in 2013-14. Figure 4 shows a steady increase in transportation over the years. Skewed procurement practices are also instrumental to this.

3.4b Multiple loading and unloading: Starting from procurement in the mandis (village huts) to the distribution in the fair price shops, food grains pass through multiple loading and unloading stations. As a result, not only the cost of operation rises, quantity loss and quality degradation of the food grains also result as a consequence. Multiple loading and unloading also lead to a substantial amount of transportation delay.

3.4c Lack of coordination: During 2006-07 to 2011-12, actual movement of food grains was between 84 and 94 per cent of the planned movement. The shortfall is due to the shortage in the supply of railway rakes because of a lack of coordination between FCI and Indian Railways. The shortfall in transportation leads to accumulation of food grain in the high procuring states, which, in the end, causes loss and quality deterioration of a huge amount of food grains. Proper information sharing is an important requirement for better coordination between FCI and Indian Railways.

3.4d Potential future: Requirement of transportation is driven by the gap between demand and procurement in the deficit region. Augmenting transportation capabilities is, therefore, a need of the hour. Recent initiatives such as use 
of riverine, multimodal transportation, and National Waterways (NWs) [25] are important in this context. Early completion of Dedicated Freight Corridor (DFC) for achieving higher productivity and reduction in unit transportation cost will increase transportation capacity and efficiency. An augmented transportation capacity would help in reducing storage space requirement in procuring regions as well as in reducing unnecessary food grain handling and transportation delays. High Level Committee [19] proposed containerized transportation of food grains that will make the process more efficient. Recent research works [26-29] also stress on the need of proper planning for efficient transportation of food grain.

\subsection{Distribution}

3.5a Lack of eligibility checking: Researchers and policy makers have studied distribution of food grains extensively over the years [1, 7, 30-33]. Planning Commission of India [33] found that only 42 per cent of the subsidized grains reach the targeted people. Significant inefficiency lies in identifying targeted people due to biased practices [31, 33]. As a result, the process of identification of the targeted people is plagued with errors of inclusion (of non-poor) and exclusion (of poor). Digitization of ration cards has removed about 20 to 30 million duplicate and bogus ration cards in the last few years. Linking of ration card with a unique identity card (Aadhar card) would further streamline the process.

3.5b Fanancial viability: Financial viability of Fair Price Shops (FPSs) is crucial to the success of the Indian food programme. More than 500,000 FPSs work at the final stages of the distribution. Various studies [30, 33, 34] have found that the financial viability of the fair price shops (FPSs) is in question with a presence of leakage and diversion of subsidized food in these shops. Lack of financial viability will remain a weak area in the distribution chain in ensuring food grain to the targeted people. Implementation of doorstep delivery, increase in commission, and other viable business models are necessary to make this possible.

$3.5 \mathrm{c}$ Leakage of food grain: Planning Commission of India [33] has estimated that as much as 36 per cent of the budgetary subsidies are taken off the supply chain, and another 21 per cent only reach unintended people. Jha et al [30] have reported that the government spent as much as INR (Indian Rupees) 8.5 to transfer INR 1 to the poor. Gulati and Saini [1] found that just five states (Uttar Pradesh, Bihar, Madhya Pradesh, Maharashtra and West Bengal) contribute to 50 per cent of total leakage of food grains while these states account for 60 per cent of the poor.

Table 2 shows the food grain offtake details in the last decade. It can be found that both Public Distribution System (PDS) offtake and open market sales have gone up substantially resulting in a large central pool stock.
Table 2. Food grain offtake details from 2006-07 to 2015-16 (in MMT). Source: Food Corporation of India.

\begin{tabular}{lcccc}
\hline Year & $\begin{array}{c}\text { Public } \\
\text { Distribution } \\
\text { System (PDS) }\end{array}$ & $\begin{array}{c}\text { Other Welfare } \\
\text { Schemes } \\
\text { (OWS) }\end{array}$ & $\begin{array}{c}\text { Open } \\
\text { Market } \\
\text { Sales }\end{array}$ & Total \\
\hline $2006-07$ & 31.44 & 5.10 & 0.18 & 36.73 \\
$2007-08$ & 33.12 & 4.33 & 0.02 & 37.47 \\
$2008-09$ & 34.65 & 3.67 & 1.24 & 39.56 \\
$2009-10$ & 42.70 & 5.17 & 2.16 & 50.03 \\
$2010-11$ & 47.40 & 4.28 & 1.32 & 53.00 \\
$2011-12$ & 50.96 & 4.12 & 1.20 & 56.28 \\
$2012-13$ & 51.46 & 4.35 & 6.97 & 62.78 \\
$2013-14$ & 46.73 & 4.40 & 6.28 & 57.41 \\
$2014-15$ & 47.41 & 4.29 & 4.20 & 55.90 \\
$2015-16$ & 51.76 & 4.30 & 7.59 & 63.65 \\
\hline
\end{tabular}

Table 3. Status of Public Distribution System. Source: E-Book of Department of Food and Public Distribution, India, 2016.

\begin{tabular}{lc}
\hline Implementation Issues & Dec, 2016 \\
\hline Fair Price Shops automated & 176,835 \\
Digitization of ration cards & $100 \%$ \\
Aadhar linking of ration cards & $71.13 \%$ \\
On line allocation of food grains started & 29 States/ \\
& UTs \\
Supply chain computerized & 19 States/ \\
Toll free numbers/ online grievance redressal system & UTs \\
$\quad$ implemented & UTs \\
Direct Cast Transfer in PDS launched & 3 UTs \\
\hline
\end{tabular}

Indian government has taken a number of steps to improve the public distribution system. Table 3 shows the status of the PDS in India in December 2016. Effective administration supported by digitization can potentially remove quite a number of bottlenecks in the PDS operations.

3.5d Potential for future: Continuation of digitization process and early completion of linking of ration cards with unique identity cards (Aadhar cards) would remove duplicate ration cards although the process has its challenges from difficulties in ensuring complete coverage across the country, ensuring secure operations and information sharing, and protecting privacy of the individuals. Implementation of real time checking will ensure proper beneficiary selection without human intervention. In order to reduce the leakage of food grain, Saini et al [35] have proposed the implementation of Direct Benefit Transfer (DBT) for the Indian food programme. Sometimes, it is also proposed to provide cash to the targeted people instead of subsidized food grain. However, in a study of 1200 households in nine states, Khera [32] has showed that two-thirds of the people 


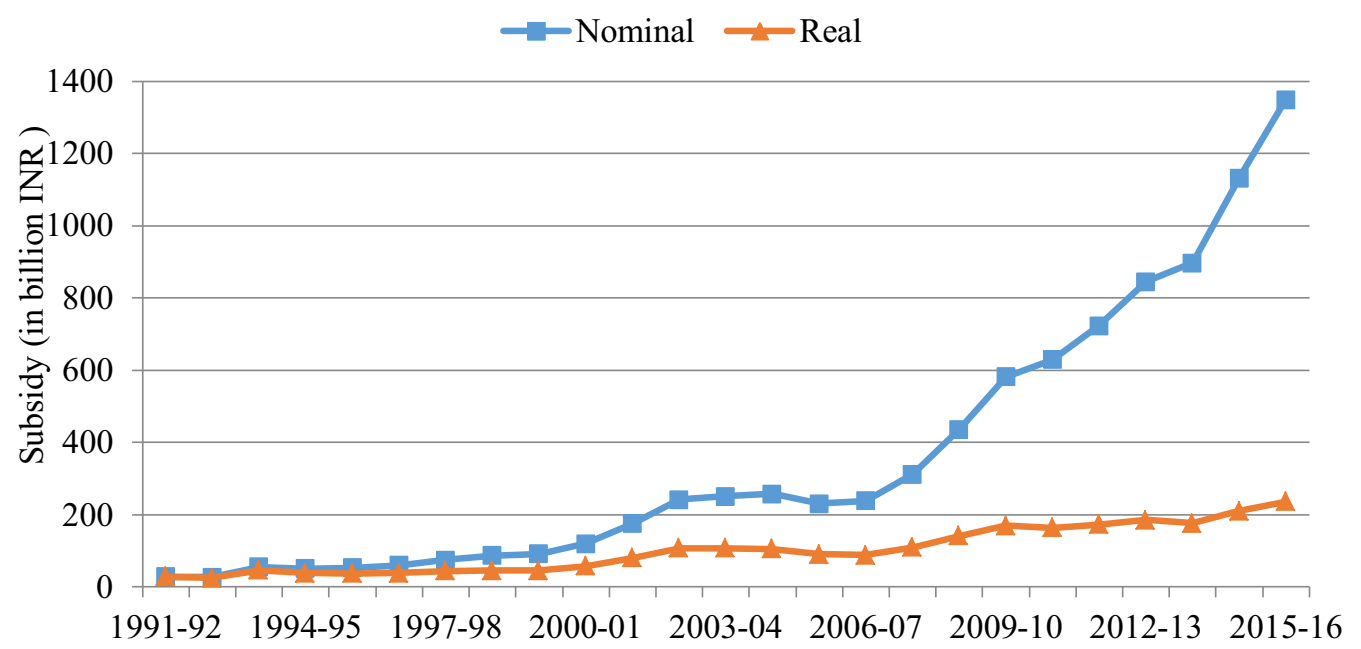

Figure 5. Food subsidy since 1991-92. Data Source: Annual Reports of DFPD (various issues).

prefer food over cash. It is evident that no single policy can be perfect for a diverse country like India. Sometimes even a proper policy fails to achieve its targets due to inefficient implementation.

\subsection{Financial}

Financial sustainability is the most important factor for the continuation of the present food programme. Figure 5 shows the details of food subsidy since 1991-92 both in real and nominal terms. Food subsidy has gone up by 47 times in the last 24 years. Even in real terms, the increase is by more than 8 times. In fact, figure 5 shows that, in the last decade, the food subsidy has increased in leaps and bounds. Based on the High Level Committee report [19], it is observed that product cost contributes around 70 per cent, procurement incidentals contribute around 17 per cent and distribution cost contributes the remaining 13 per cent of the total operational costs. Transportation cost is the major contributor of the distribution cost at around 5 per cent with the remaining 8 per cent being the costs of interests, storage, handling, interests, losses, and administration.

3.6a Increasing demand: Due to increasing population, food grain demand will be increasing with every passing day. This increasing demand is a major contributor to food subsidy. The PDS demand can be estimated at about 58 MMT in 2018. Moreover, there will be additional demand of almost 0.8 MMT every year as per NFSA Act. Therefore, strict eligibility checks and review of the eligibility limits from time to time may be carried out for smooth functioning of the food program.

3.6b Increasing gap between economic cost and issue price: Economic Cost (EC) is the unit operational cost whereas Central Issue Price (CIP) is the price at which food grains are distributed to targeted people. Under the National Food
Security Act (NFSA), CIP has been reduced to INR 3 per $\mathrm{kg}$ of rice and INR 2 per $\mathrm{kg}$ of wheat, respectively (less than 10 per cent of market price for both rice and wheat), which was earlier INR 4.15 for people below poverty level (BPL) and INR 6.10 for people above poverty level (APL) in case of wheat and INR 5.65 for BPL and INR 8.30 for APL in case of rice. Figure 6 shows the price gap between EP and CIP (taking average of APL and BPL price) over the last decade. The price gap has increased by almost five times over the same period.

3.6c Increasing support price: Major contributor of EC is the cost of food grain i.e., MSP at which procurement is done. MSP, which is mainly driven by cost of cultivation, shares 70 per cent of EC. Therefore, reduction of cost of cultivation should be an important component for subsidy reduction.

With the increasing demand and higher EC, it is indeed very difficult for any nation to sustain a large-scale food programme. There will also be challenges of maintaining a 10 per cent ceiling on domestic support as per the Trade Facilitation Agreement (TFA). This means that there will be limits to various subsidies in agriculture ranging from price support to farmers, fertilizer subsidy, and subsidies to food grains. This would entail efficient management of the food programme, implementation of policies to make the farmers self-reliant through better credit facility, insurance, modern equipment, and innovation, and building of competitive and transparent open markets. Shah [36] describes that it will be unfair to put a ceiling on domestic support for India where 800 million Indians will continue to live in rural areas by 2050 .

3.6d Large work force: Presence of a large workforce at FCI is an important factor contributing to financial burden of the food programme in India. Total workforce at FCI includes 16,000 departmental workers, 26,000 Direct 


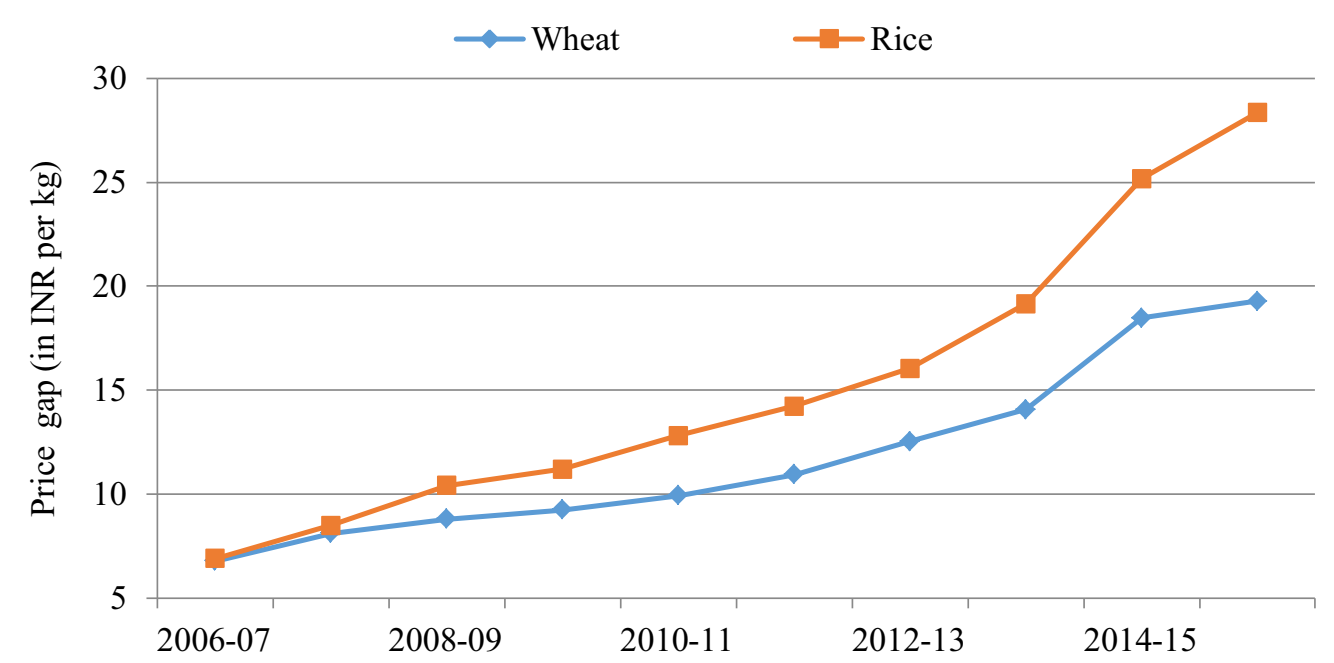

Figure 6. Price gap between EC and CIP for rice and wheat. Data Source: Food Corporation of India.

Payment System (DPS) workers and around 0.1 million contract workers [19].

3.6e Potential for future: Certainly, the financial burden in the form of a very high subsidy is not going to reduce much unless and until there is a substantial reduction in targeted people or a similar increase in CIP. Apart from that, both central and state government must invest in terms of modern technology, best practices, assured irrigation and better financial credit to reduce the cost of cultivation. A positive direction, other than that, is to improve the logistics in the food programme and eliminate leakage which may reduce the economic cost (EC) considerably. High Level Committee [19] has proposed to reduce the priority household to 40 per cent instead of almost 67 per cent of total population at present, and to set CIP at 50 per cent of EC for non-AAY families (poorest of the poor). Nevertheless, implementation of this decision will be more political than economical, as providing subsidized food grains is an attractive populist measure. However, the scenario may change if people voluntary give up the subsidy. For example, around 10 million households in India have voluntarily given up the LPG subsidy in recent time [37]. Digitization of the beneficiaries has already removed a large number of bogus beneficiaries.

\subsection{Organizational}

3.7a Payment disparity: High Level Committee [19] has found that payment disparity among the workforce in the food program is a reality. While a departmental worker gets around INR 79,500 per month, a DPS worker gets INR 26,000 per month and a Contract worker gets only INR 10,000 per month. Due to significant variation in payment, lower paid workers have a demand for higher pay [38].
Once the authority approves their demand, the annual labor cost will be increased by INR 16 billion.

3.7b Resistance to labor reforms: Involvement of huge amount of workforce becomes a challenge to any structural change. With increasing mechanization and automation, the need for reorganization of workforce will arise. Recently, the government has allowed FCI to hire contract labors in 226 depots where only departmental labors were engaged. FCI is also allowed to transfer departmental labors to other depots as and when required [39]. As a result, FCI can save around INR 60 billion.

\section{Proposed framework}

In this section, we have proposed a framework for efficient implementation of the National Food Programme. A conceptual diagram of the proposed framework is shown in figure 7. Information sharing among the key stakeholders of the food programme through a cloud system is at the heart of the proposed framework. Government's action under this programme starts with procurement and ends with distribution of food grains to the eligible people. We have added eligibility tracking for efficient utilization of the programme. 'How much to procure' and 'from where to procure' are two key questions in the procurement planning. Answer to the first question may be obtained through forecasting based on real-time eligibility tracking. Based on production and real-time stock data, procurement schedule can be prepared. Item level tracking is possible using RFID in storage, transformation and distribution i.e., until the last mile delivery. Use of RFID from perishable items [40] to non-perishable items is possible because of decreasing cost of implementation. It is becoming viable for government 


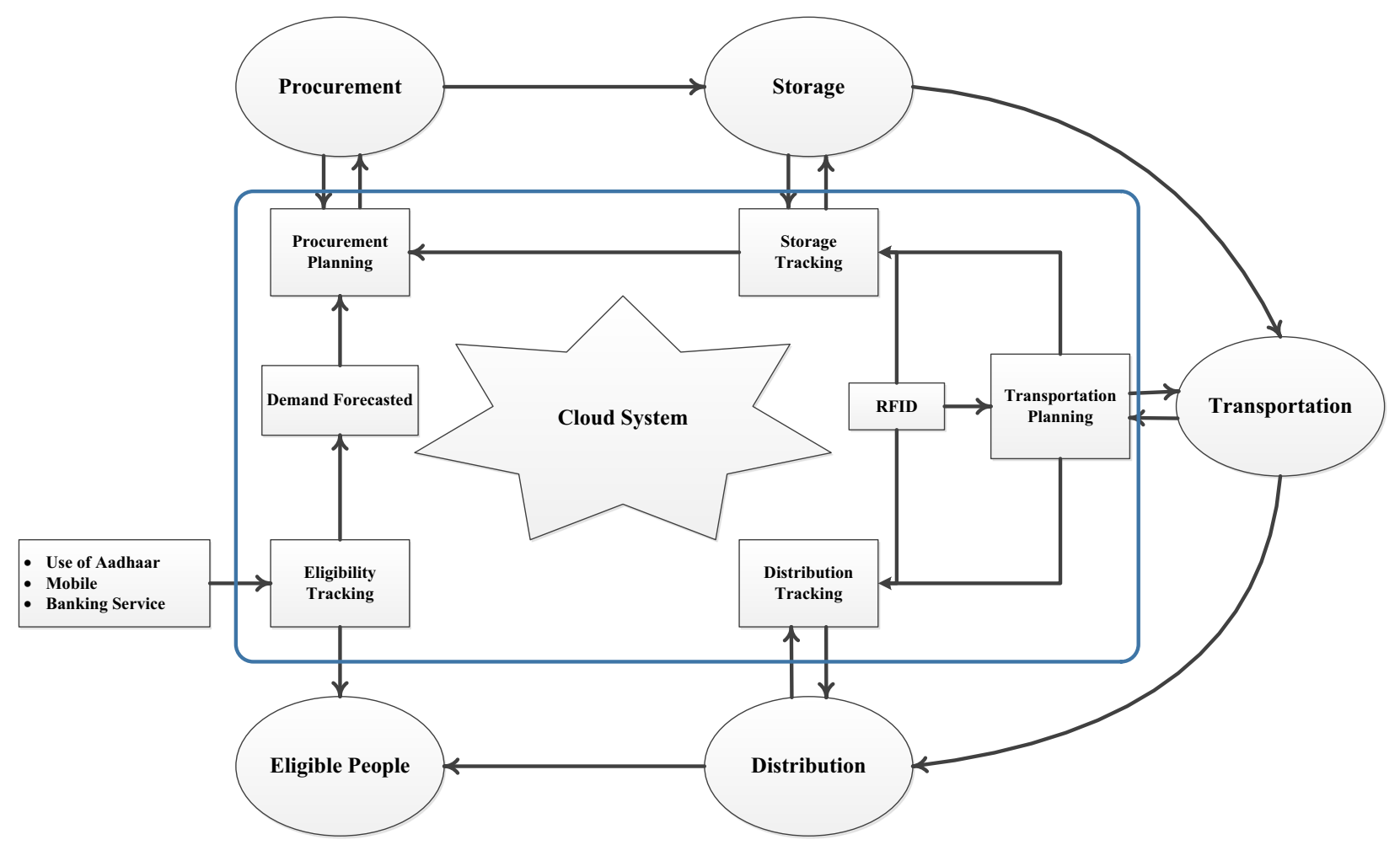

Figure 7. Digital framework for National Food Programme: A conceptual diagram.

also to implement RFID enabled distribution system considering the potential benefits.

Few policies can be incorporated in the framework for effective management of the programme. Change is needed in the present procurement policies of the government as the present policy leads to concentrated storage in a relatively few storage areas which is invariably followed by excessive transportation of food grain. An option to follow is to go for 'Competitive Procurement' instead of 'Open Procurement' policy. Taking insights from Fampa et al [41], a game theoretical framework can be built for the reduction of operational cost. It can be found that under 'Competitive Procurement', government will buy more from the states where the operational costs are less. This may also help in balancing private and public procurement. No state would then depend totally on public procurement.

Distributed procurement is required instead of present concentrated procurement to spread out storage requirement and reduce transportation needs. Phasing out of old storage practices (mainly CAP) needs to be speeded up along with the setting up of silos. These steps will help in better stock management with integrated digital platform for real-time access. On a broader perspective, we also propose the introduction of flexible and agile supply chain to handle emergency as is found in a humanitarian supply chain [42].
We found that steep wheat procurement for a few months creates peak storage requirements for that period necessitating the use of CAP and open storage to stock the additional quantity. This results in substantial additional costs as well as loss of food grain due to inadequate storage. Policy measures such as additional advanced distribution of wheat during the procurement season and/or evenly distributed procurement of wheat can save a considerable amount of storage requirement and improve overall capacity utilization. These policies can potentially eliminate even the use of CAP under the present working scenarios. Moreover, increasing 'month of stocking' to three or four instead of two as at present will add more flexibility to the distribution system without any additional cost.

Improper identification of targeted people for providing subsidized food grains is a major source of inefficiency. The government plan of using JAM (Jhan dhan Account, Aadhar and Mobile phone) would go a long way in ensuring real time eligibility checking. This way, exclusion of creamy layer can be done very effectively without any human prejudice. In addition, implementation of real-time beneficiary tracking and use of RFID [43] for item level tracking will remove major deficiencies of the distribution system. However, the implementation of the same would need upfront investment, maintenance and training of the personnel. 


\section{Impact on global market}

India has been one of the key exporters of rice apart from Thailand and Vietnam. Based on USDA, India produced around 22 per cent of global rice production (TE 2013-14), and exported more than 10 MMT in 2012-13 and 2013-14, which was almost 10 per cent of its total production. Naturally, if domestic production goes up in India, food availability in the global market will also go up and thus, one of the key objectives of 'Food Security' will be achieved. On the other hand, less export or ban on export can certainly raise price volatility. During 2008 to early 2011, India only exported around 2.5 MMT annually. Many researchers $[44,45]$ found that ban on rice export was one of the main reasons behind the price rise during 2007-08. However, India had the maximum central pool stock during the same period. A proper export policy coupled with an appropriate policy of food grain procurement and storage is crucial not only to achieve price and supply stability within the country but also to maintain a steady supply of food grains in the global market.

\section{Conclusion}

In this paper, an attempt has been made to present various issues and challenges of the Indian food programme. At the same time, potential capabilities to resolve these issues and challenges are also discussed. Right blending of various consistent policies will improve the state of the food programme and ensure food security in the country. Lower yield, small farmland size, and lack of irrigation are major problems related to the production of food grain in India. Land reforms, better irrigation, financial assistance through banking service, and adequate government support to handle uncertainties will not only help in augmenting food production but also will help in reducing the cost of cultivation. An appropriate price support programme is required to ensure fair food grain price to the farmers. At the same time, concerned agencies should start 'competitive procurement' instead of 'open procurement' in high procuring states, which will bring a much-needed balance between private and public procurement of food grain. Popularization of e-NAM has the potential to integrate individual markets into a single unified market, thus creating a winwin situation for both farmers and traders.

Setting up modern storage facilities and phasing out of CAP will ensure better stock holding. This will not only reduce storage loss but also will reduce losses due to multiple loading and unloading along with their associated cost and time. With enhanced transportation facilities through the use of Dedicated Freight Corridor (DFC) and National Waterways (NWs), FCI can easily transport any amount of food grain from one part of the country to another much faster and more efficiently. Implementation of containerized food grain transportation will eliminate transit loss and at the same time improve the turn-around time. Distribution system is improving fast through steps such as end-to-end computerization, digitization of ration cards, and doorstep delivery of food grains for FPS. Reduction of food subsidy will remain a challenge due to increasing demand and a widening gap between economic cost (EC) and central issue price (CIP). Ensuring real-time checking of targeted people for receiving subsidized food grain may cap the increasing demand to some extent.

Mechanization of various activities and labor reforms must be synchronized for continuation of the program efficiently. Use of RFID will ensure item tracking from storage to offtake of food grains to the targeted people and real-time information will help in proper planning at every stage. The authors believe that the steps mentioned in the paper will help in eliminating bottlenecks and leakage in their respective areas and increase food availability within the country as well as beyond the country.

\section{Acknowledgements}

This work was supported by the project titled 'Strategic Modeling for Sustainable Food Security (SFF)' sponsored by Ministry of Human Resource and Development (MHRD), Department of Higher Education, Government of India [Sanction letter No. F. NO. 4-25/2013-TS-I].

\section{References}

[1] Gulati A and Saini S 2015 Leakages from Public Distribution System (PDS) and the Way Forward, available at http:// icrier.org/pdf/Working_Paper_294.pdf

[2] FAO, IFAD and WFP 2015 The State of Food Insecurity in the World. Meeting the 2015 international hunger targets: taking stock of uneven progress, available at http://www.fao. org/3/a-i4646e.pdf

[3] Acharya S, Chand P, Birthal S and Negi D 2012 Market Integration and Price Transmission in India: A Case of Rice and Wheat with Special Reference to the World Food Crisis of 2007/08, available at http://www.fao.org/3/a-an034e.pdf

[4] Mallory M and Baylis K 2012 The food corporation of india and the public distribution system: impacts on market integration in wheat, rice, and pearl millet. J. Agribus. 30: 225-250

[5] Sekhar C S C 2012 Agricultural market integration in India: an analysis of select commodities. Food Policy 37: 309-322

[6] Banerjee O, Darbas T, Brown P R and Roth C H 2014 Historical divergence in public management of foodgrain systems in India and Bangladesh: opportunities to enhance food security. Glob. Food Secur. 3: 159-166

[7] Suryanarayana M H 1995 PDS: beyond implicit subsidy and urban bias-the Indian experience. Food Policy 20: 259-278

[8] Cummings R, Rashid S and Gulati A 2006 Grain price stabilization experiences in Asia: what have we learned? Food Policy 31: 302-312 
[9] Saini S and Kozicka M 2014 Evolution and Critique of Buffer Stocking Policy of India, available at http://icrier.org/ pdf/Working_Paper_283.pdf

[10] Sharma P and Gulati A 2012 Approaches to Food Security in Brazil, China, India, Malaysia, Mexico, and Mexico, and Nigeria: Lessons for Developing Countries, available at http://icrier.org/pdf/Policy_Series_No_14.pdf

[11] Yu W, Elleby C and Zobbe H 2015 Food security policies in India and China: implications for national and global food security. Food Secur. 7: 405-414

[12] PTI 2016 India's crop yields lower than US, Europe and China: Radha Mohan Singh, http://indianexpress.com/arti cle/india/india-news-india/india-crops-agriculture-radhamohan-singh-4389510/

[13] Department of Agriculture \& Cooperation (DAC) 2014 Agricultural Statistics at a Glance 2014, available at http:// eands.dacnet.nic.in/PDF/Agricultural-Statistics-AtGlance2014.pdf

[14] Aiyar S S A 2015 Why two consecutive droughts don't affect India the way it used to? http://economictimes.indiatimes. com/news/economy/agriculture/why-two-consecutivedroughts-dont-affect-india-the-way-it-used-to/articleshow/ 50061996.cms

[15] Birthal P S, Negi D S, Khan M T and Agarwal S 2015 Is Indian agriculture becoming resilient to droughts? Evidence from rice production systems. Food Policy 56: 1-12

[16] Balani S 2013 Functioning of the Public Distribution System, available at http://www.prsindia.org/administrator/uploads/ general/1388728622 TPDS\%20Thematic\%20Note.pdf

[17] Deepa N and Ganesan K 2016 Mahalanobis Taguchi system based criteria selection tool for agriculture crops. Sadhana 41: 1407-1414

[18] Tilman D, Balzer C, Hill J and Befort B L 2011 Global food demand and the sustainable intensification of agriculture. Proc. Natl. Acad. Sci. 108: 20260-20264

[19] Government of India 2015 Report of High Level Committee on Reorienting the Role and Restructuring of Food Corporation of India, available at http://fci.gov.in/report-publica tion.php?view $=216$

[20] Gulati A, Gujral J, Nandakumar T, Jain S, Anand S, Rath S and Joshi P 2012 National Food Security Bill Challenges and Options, available at http://www.prsindia.org/uploads/media/ Food $\% 20$ Security/CACP\%20Report\%20on\%20Food\% 20Security\%20Bill.pdf

[21] Department of Food and Public Distribution 2015 Annual Report 2015-16 (and Various Issues). Ministry of Consumer Affairs, Food \& Public Distribution; Government of India, availabe at http://dfpd.nic.in/

[22] Devi S P, Narahari Y, Viswanadham N, Kiran S V and Manivannan S 2015 E-Mandi implementation based on GaleShapely algorithm for perishable goods supply chain. In: IEEE International Conference on Automation Science and Engineering pp. 1421-1426, https://doi.org/10.1109/coase. 2015.7294297

[23] Viswanadham N, Chidanda S, Narahari Y and Dayama P 2012 Mandi electronic exchange: orchestrating indian agricultural markets for maximizing social welfare. In: IEEE International Conference on Automation Science and Engineering pp. 992-997, https://doi.org/10.1109/coase.2012.6386465

[24] CAG 2013 Storage Management and Movement of Food Grains in Food Corporation of India, available at http://www. cag.gov.in/content/report-no-7-2013-performance-audit-sto rage-management-and-movement-food-grains-food

[25] Prabhakar B 2015 Inland waterways: how Nitin Gadkari is steering some of modern India's biggest infrastructure projects, http://articles.economictimes.indiatimes.com/2015-0208/news/58928590_1_nitin-gadkari-national-waterways-mod ern-india

[26] Mogale D G, Kumar S K, Márquez F P G and Tiwari M K 2017 Bulk wheat transportation and storage problem of public distribution system. Comput. Ind. Eng. 104: 80-97

[27] Maiyar L M and Thakkar J J 2017 A combined tactical and operational deterministic food grain transportation model: particle swarm based optimization approach. Comput. Ind. Eng. 110: 30-42

[28] Mogale D G, Dolgui A, Kandhway R, Kumar S K and Tiwari M K 2017 A multi-period inventory transportation model for tactical planning of food grain supply chain. Comput. Ind. Eng. 110: 379-394

[29] Tanksale A and Jha J K 2017 Solving multi-region multifacility inventory allocation and transportation problem: a case of Indian public distribution system. Comput. Ind. Eng. 110: $175-190$

[30] Jha R, Gaiha R, Pandey M K and Kaicker N 2013 Food subsidy, income transfer and the poor: a comparative analysis of the public distribution system in India's states. $J$. Policy Model. 35: 887-908

[31] Kumar B and Mohanty B 2012 Public distribution system in rural india: implications for food safety and consumer protection. Proc. Soc. Behav. Sci. 65: 232-238

[32] Khera R 2014 Cash vs. in-kind transfers: Indian data meets theory. Food Policy. 46: 116-128

[33] Planning Commission 2005 Performance Evaluation of Targeted Public Distribution System (PDS), available at http://planningcommission.nic.in/reports/peoreport/peo/peo_ tpds.pdf

[34] Khera R 2011 India's public distribution system: utilisation and impact. J. Dev. Stud. 47: 1038-1060

[35] Saini S, Sharma S, Gulati A, Hussain S and von Braun J 2017 Indian food and welfare schemes: scope for digitization towards cash transfers, available at http://icrier.org/pdf/ Working_Paper_343.pdf

[36] Shah M 2014 Food security and Rodrik's trilemma, http:// www.thehindu.com/opinion/op-ed/food-security-androdriks-trilemma/article6313910.ece?ref=relatedNews

[37] Dutta S 2016 PM Modi's campaign: One crore households give up LPG subsidy, http://timesofindia.indiatimes.com/ india/PM-Modis-campaign-One-crore-households-give-upLPG-subsidy/articleshow/51931982.cms

[38] Das S 2014 Battle royale brewing at FCI over equal-workequal-pay, http://indianexpress.com/article/business/econ omy/battle-royale-brewing-at-fci-over-equal-work-equalpay/\#sthash.DU1Kpsd2.dpuf

[39] Das S 2016 Labour reform? FCI to save Rs $600 \mathrm{cr}$ under new hiring norm, http://www.financialexpress.com/economy/ labour-reform-fci-to-save-rs-600-cr-under-new-hiring-norm/ 341804/

[40] Chande A, Dhekane S, Hemachandra N and Rangaraj N 2005 Perishable inventory management and dynamic pricing using RFID technology. Sadhana 30: 445-462

[41] Fampa M, Barroso L A, Candal D and Simonetti L 2008 Bilevel optimization applied to strategic pricing in 
competitive electricity markets. Comput Optim Appl. 39:121-142

[42] Jha A, Acharya D and Tiwari M K 2017 Humanitarian relief supply chain: a multi-objective model and solution. Sadhana 42: 1167-1174

[43] Biswal A K, Jenamani M and Kumar S K 2018 Warehouse efficiency improvement using RFID in a humanitarian supply chain: Implications for Indian food security system. Transp. Res. E. 109:205-224

[44] Dorosh P A and Rashid S 2013 Trade subsidies, export bans and price stabilization: lessons of Bangladesh-India rice trade in the 2000s. Food Policy 41: 103-111

[45] Rude J and An H 2015 Explaining grain and oilseed price volatility: the role of export restrictions. Food Policy 57: 83-92 